San Jose State University

SJSU ScholarWorks

Master's Theses

Master's Theses and Graduate Research

1992

\title{
Isolation and characterization of chenopodin, the major seed storage protein of quinoa (chenopodium quinoa)
}

Saraswathi Goundan

San Jose State University

Follow this and additional works at: https://scholarworks.sjsu.edu/etd_theses

\section{Recommended Citation}

Goundan, Saraswathi, "Isolation and characterization of chenopodin, the major seed storage protein of quinoa (chenopodium quinoa)" (1992). Master's Theses. 389.

DOI: https://doi.org/10.31979/etd.5mbw-bwpe

https://scholarworks.sjsu.edu/etd_theses/389

This Thesis is brought to you for free and open access by the Master's Theses and Graduate Research at SJSU ScholarWorks. It has been accepted for inclusion in Master's Theses by an authorized administrator of SJSU ScholarWorks. For more information, please contact scholarworks@sjsu.edu. 


\section{INFORMATION TO USERS}

This manuscript has been reproduced from the microfilm master. UMI films the text directly from the original or copy submitted. Thus, some thesis and dissertation copies are in typewriter face, while others may be from any type of computer printer.

The quality of this reproduction is dependent upon the quality of the copy submitted. Broken or indistinct print, colored or poor quality illustrations and photographs, print bleedthrough, substandard margins, and improper alignment can adversely affect reproduction.

In the unlikely event that the author did not send UMI a complete manuscript and there are missing pages, these will be noted. Also, if unauthorized copyright material had to be removed, a note will indicate the deletion.

Oversize materials (e.g., maps, drawings, charts) are reproduced by sectioning the original, beginning at the upper left-hand corner and continuing from left to right in equal sections with small overlaps. Each original is also photographed in one exposure and is included in reduced form at the back of the book.

Photographs included in the original manuscript have been reproduced xerographically in this copy. Higher quality $6 " \mathrm{n} 9$ " black and white photographic prints are available for any photographs or illustrations appearing in this copy for an additional charge. Contact UMI directly to order.

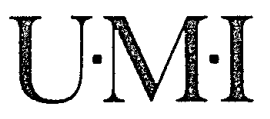

University Microfilms Internatıonal

A Bell \& Howell Inlormation Company

300 North Zeeb Road. Ann Arbor, MI 48106-1346 USA

$313: 761-4700 \quad 800: 521.0600$ 

Order Number 1350083

Isolation and characterization of chenopodin, the major seed storage protein of quinoa (Chenopodium quinoa)

Goundan, Saraswathi, M.A.

San Jose State University, 1992

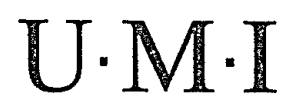

300 N. Zeeb Rd.

Ann Arbor, MI 48106 


\section{.}




\title{
ISOLATION AND CHARACTERIZATION OF CHENOPODIN, THE MAJOR SEED STORAGE PROTEIN OF QUINOA (CHENOPODIUM QUINOA)
}

\author{
A Thesis \\ presented to \\ The Faculty of the Department of Biological Sciences \\ San Jose State University
}

In Partial Fulfillment

of the Requirements for the Degree

Master of Arts

By

Saraswathi Goundan

August, 1992 
APPROVED FOR THE DEPARTMENT OF BIOLOGICAL SCIENCES
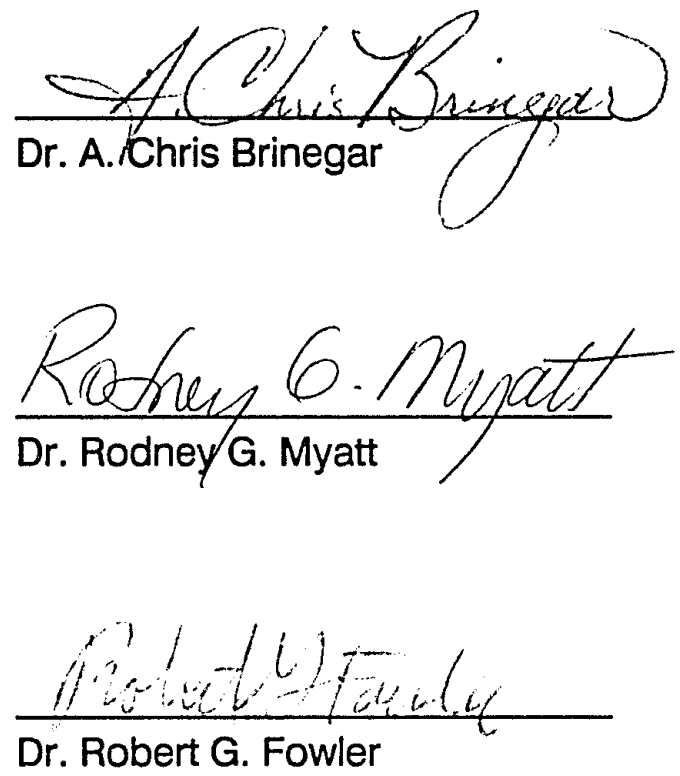

Dr. Robert G. Fowler

APPROVED FOR THE UNIVERSITY

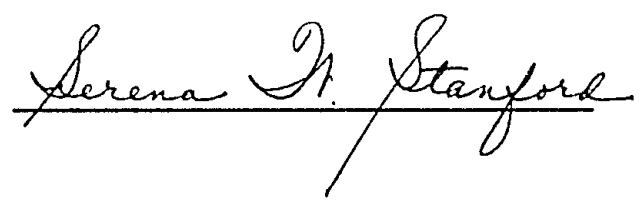




\section{ABSTRACT \\ ISOLATION AND CHARACTERIZATION OF CHENOPODIN, THE MAJOR SEED STORAGE PROTEIN OF QUINOA (CHENOPODIUM QUINOA)}

By Saraswathi Goundan

Optimal conditions were determined for the extraction of seed proteins from quinoa (cv. Ancient Harvest). Extraction in $0.5 \mathrm{M} \mathrm{NaCl}, 50 \mathrm{mM}$ Tris- $\mathrm{HCl}$ (pH 8.0) for $1 \mathrm{hr}$ at room temperature at a buffer to flour ratio of $10 \mathrm{ml} / \mathrm{g}$ yielded approximately $65 \mathrm{mg}$ protein per $\mathrm{g}$ flour. Chenopodin, the $11 \mathrm{~S}$ storage protein of quinoa was enriched by precipitation at $\mathrm{pH} 5.0$ and purified by gel filtration chromatography. The $A(32-39 \mathrm{kDa})$ and $B(22-23 \mathrm{kDa})$ chenopodin subunits were isolated by ion exchange chromatography after denaturation, reduction, and carboxymethylation of the native chenopodin $(316 \mathrm{kDa})$. The amino acid composition of chenopodin was similar to other $11 S$ storage proteins. The $A$ subunit was higher in glycine, methionine, and hisdidine than the B subunit, but lower in alanine, leucine, and phenylalanine. 


\section{ACKNOWLEDGMENTS}

I would like to acknowledge Dr. Chris Brinegar for his advice and encouragement. Dr. Brinegar's patience and understanding during the whole time is deeply appreciated. Thanks to Dr. Fowler and Dr. Myatt for their support and involvement. Thanks also to the Faculty of the Biclogy Department, and the staff of the Biology Department Office, Microbiology Service Center, and Photography Department at the Instructional Research Center for their help and cooperation. Special thanks to Dr. Pitts for her advice and initial guidance towards biological studies.

I would like to express my gratitude to my friends for making my life joyful. The generous help and support provided by Gayatri and Suvarna is greatly appreciated. Finally, I would like to thank my husband for his encouragement, our beloved children Kannan, Appu and Poorani for their endurance, and Thambi for his help. 


\section{TABLE OF CONTENTS}

PAGE

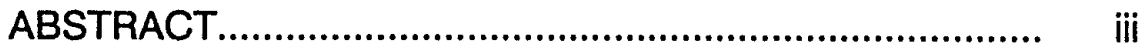

ACKNOWLEDGMENTS................................................. iv

LIST OF FIGURES....................................................... vi

LIST OF TABLES.......................................................... vii

INTRODUCTION................................................................. 1

MATERIALS AND METHODS........................................... 9

RESULTS AND DISCUSSION......................................... 13

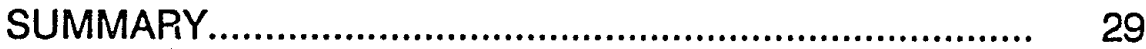

LITERATURE CITED.................................................. 31 


\section{LIST OF FIGURES}

FIGURE

PAGE

1. Mechanism for $11 \mathrm{~S}$ protein synthesis.......................................... 7

2. SDS-PAGE of quinoa seed protein extracted with different salt concentrations......................................................

3. SDS-PAGE analysis of protein precipitated at various $\mathrm{pH}$ 's. 20

4. Sepharose $\mathrm{CL}-6 \mathrm{~B}$ gel filtration of $\mathrm{pH} 5.0$ precipitated quinoa protein..................................................................... 22

5. SDS-PAGE analysis of the gel filtration protein fractions.......... 23

6. SDS-PAGE analysis of alkylated versus unakylated chenopodin.

7. DEAE sepharase CL-6B ion exchange chromatography of alkylated protein....................................................................... 25

8. SDS-PAGE analysis of DEAE ion exchange chromatography fractions. 


\section{LIST OF TABLES}

\section{TABLE}

I. Nutritional analysis comparisons of various grains including quinoa........................................................................ 4

II. Effect of extraction time on protein yield................................. 14

III. Effect of extraction volume on protein yield............................ 15

IV. Effect of $\mathrm{NaCl}$ salt concentration on the protein yield.............. 16

V. Recovery of acid precipitated protein..................................... 19

VI. Amino acid composition of chenopodin and its

$A$ and $B$ subunits............................................................ 28 


\section{Introduction}

Quinoa, Chenopodium quinoa, is a grain crop that comes from the high Andes of Peru, Bolivia and Chile in South America. It has been cultivated in the Andes since at least 3,000 B.C. (Wood, 1985). The Incas called it "The mother grain" and it is still a popular staple food among their Andean descendants, along with potatoes and maize. Limited production of this crop occurs in the United States, primarily in the Rocky Mountain region centered in Colorado, and is limited by temperature to altitudes between 7,000 and 10,000 feet (Johnson and Croissant, 1985).

Quinoa is not a true cereal grain but is technically a dicotyledenous herb in the Chenopodiaceae family. Chenopodium plants have characteristic leaves shaped like a goose foot. Quinoa is an annual that grows from 3-6 feet high, and like millet its seeds are in large clusters at the end of the stalk. Quinoa seeds are small in size, with a shape and color similar to cross between sesame seed and millet. Seeds are disc shaped with a flattened or depressed equatorial band around their periphery. The seeds are usually a pale yellow color, but some species may vary from almost white through pink, orange or red to purple and black (Wood, 1985).

The seeds are covered with saponin, a resin-like substance that is extremely bitter and forms a soapy solution in water. To be edible, the saponin must be removed. Traditionally saponin has been removed by laboriously hand scrubbing the quinoa in alkaline water. Some agriculturalists maintain that a saponin free strain of quinoa should be developed since its removal process has limited 
quinoa's production and marketing. On the other hand, ecologists observe that the bitter-tasting saponin probably prevents insect and bird predation and that it is better to wash away the saponin than to have to rely on insecticides.

The edible seed of the quinoa plant has been called both a pseudo-cereal and pseudo-oil seed because of its unique nutritional profile. Quinoa leaves are highly edible and are often used for livestock feed (Sokolov, 1992). Quinoa has been called one of the world's most perfect foods. One researcher (Woods, 1985) has said that "while no single food can supply all of the essential life-sustaining nutrients, it comes as close as any other in the vegetable or animal kingdom." The United Nations Food and Agriculture Organization (FAO) (Johnson and Croissant, 1985) states its quality is "equal to the protein of whole dried milk." The protein component has an amino acid profile that very closely parallels the ideal protein standard sanctified by the FAO.

Compared to other grains and vegetables quinoa is high in protein, calcium and iron although it is also high in fat. Quantitative determinations of total soluble proteins, total and free sugars, starch, total lipids, tannins, ash ( $\mathrm{Ca}, \mathrm{Na}, \mathrm{K}, \mathrm{Fe}$ and P) and caloric value were carried out on quinoa flour (Gonzalez et al., 1989). Compositional and nutritional evaluation of quinoa whole grain flour and mill fractions (Becker and Hanners, 1990; Gross et al., 1989) showed the bran contained most of the sapogenins, protein, fat, fiber and ash, while the perisperm was rich in starch. Different varieties of quinoa seed were analyzed for sapogenin (saponin precursor) content by high performance liquid chromatography. A larvae bioassay using the red flour beetle was shown to correlate with sapogenin content of the seed flour. The content of saponins was also examined since its effect on red blood cells of individuals with blood types $A$ and $O$ of the $A B O$ blood 
group series has been noted as a potential problem for the Andes population (Becker and Hanners, 1990; Gross et al., 1989).

Compared to other grains, wheat and oats come close to matching quinoa's protein content (Table I), but cereals such as barley, corn and rice generally have less than half the protein of quinoa. Quinoa seed proteins also have a good balance of amino acids and are especially high in the essential amino acids lysine, methionine, and cystine (Wood, 1985). Quinoa is a good complement for legumes which are often low in methionine and cystine. In addition, quinoa is a relatively good source of phosphorus, calcium, iron, vitamin $E$, and several of the B vitamins.

Seed protein is primarily in the form of storage protein. The storage proteins have no enzymatic activity and simply provide a source of amino acids, nitrogen and carbon skeletons for the developing seedlings. Storage proteins are deposited in the seed in an insoluble form in protein bodies and survive dessication for long periods of time. Because seeds provide an important source of protein for human and livestock nutrition, much research has been devoted to increasing the content of the essential amino acids and improving the nutritional quality of seed protein (Nelson, 1969).

Research by Osborne (1908) and Daniellson (1949) provided fundamental understanding of the chemistry of storage proteins. Under the Osborne fractionation scheme, ground, defatted seeds are successively extracted with water, salt solution, alcoholic solution, and dilute alkali or acid to yield albumins, globulins, prolamines, and glutelins, respectively. Many cereals have a high percentage of prolamines, but oats are rich in globulins. Preliminary work on quinoa seed storage proteins (Brinegar, unpublished) shows a predominance of 
Table I. Nutritional analysis comparisons (\%) of various grains including quinoa

\begin{tabular}{lcccccc}
\hline Grain & Water & Protein & Fat & $\begin{array}{c}\text { Carbo- } \\
\text { hydrate }\end{array}$ & Fiber & Ash \\
\hline Barley & 11.1 & 8.2 & 1.0 & 78.8 & 0.5 & 0.9 \\
Buckwheat & 11.0 & 11.7 & 2.4 & 72.9 & 9.9 & 2.0 \\
Corn & 72.7 & 3.5 & 1.0 & 22.1 & 0.7 & 0.7 \\
Millet & 11.8 & 9.9 & 2.9 & 72.9 & 3.2 & 2.5 \\
Oats & 12.5 & 13.0 & 5.4 & 66.1 & 10.6 & 3.0 \\
Quinoa & 11.4 & 16.2 & 6.9 & 63.9 & 3.5 & 3.3 \\
Rice & 12.0 & 7.5 & 1.9 & 77.4 & 0.9 & 1.2 \\
Rye & 11.0 & 9.4 & 1.0 & 77.9 & 0.4 & 0.7 \\
Wheat & 13.0 & 14.0 & 2.2 & 69.1 & 2.3 & 1.7
\end{tabular}

Source: Wood, R.T. Tale of a food survivor: Quinoa, East West Journal, April, 1985, pp. 64-68. 
the globulin type of storage protein. SDS-PAGE of solubility fractions (Fairbanks et al., 1990) of quinoa seed storage proteins showed that all the fractions could be classified as either albumin or globulin. All but one of the major polypeptides were in the globulin fraction. The same study showed that three globulin polypeptides of $34.3,35.6$, and $36.2 \mathrm{kDa}$ in size were highly variable within and among the accessions examined and appear to be encoded by at least two loci. Two dimensional peptide mapping revealed that these three polypeptides were homologous

Globulin storage proteins are separated into classes by cryoprecipitation, differential salt solubility, or ultracentrifugation. Most storage globulins fall into two major groups with sedimentation coefficients of $11-12 S$ and 7-8S. The seeds of many plant species contain both $11 \mathrm{~S}$ and $7 \mathrm{~S}$ storage proteins, although in most cases one or the other are predominant (Derbyshire et al., 1976). Quinoa storage globulins are mainly of the $11 S$ and $2 S$ types (Brinegar, unpublished). In many plants, the storage proteins are given trivial names derived from the genus of the plant, e.g., the 11S globulin of soybean, Glycine max, is called glycinin. In keeping with this terminology, we (Brinegar and goundan, unpublished) have recently named the quinoa $11 \mathrm{~S}$ protein as "chenopodin."

A general model has emerged for the mechanism by which storage globulins are transported from their site of synthesis, the rough endoplasmic reticulum (RER) to their site of deposition, the protein body vacuole (Fig. 1). The proteins are synthesized by membrane-bound polysomes as precursor polypeptides with amino terminal signal sequences. The signal peptide directs the translocation ofthe nascent polypeptide into the lumen of the RER and is co-translationally glycosylated by addition of mannose-containing core oligosaccharides. Soon 
Sobaต⿰亻⿻

Structure

1. Synthesis of preproglobulin

2. Removal of sienal peptide (- proglobulin)

3. Disulflde bond lormation

4. $13 t$ assembly into 85 trimer

5. Transport to protein body via Golei

6. Proteolytic processing (- globulin)

7. 2nd assembly into 115 hexamer
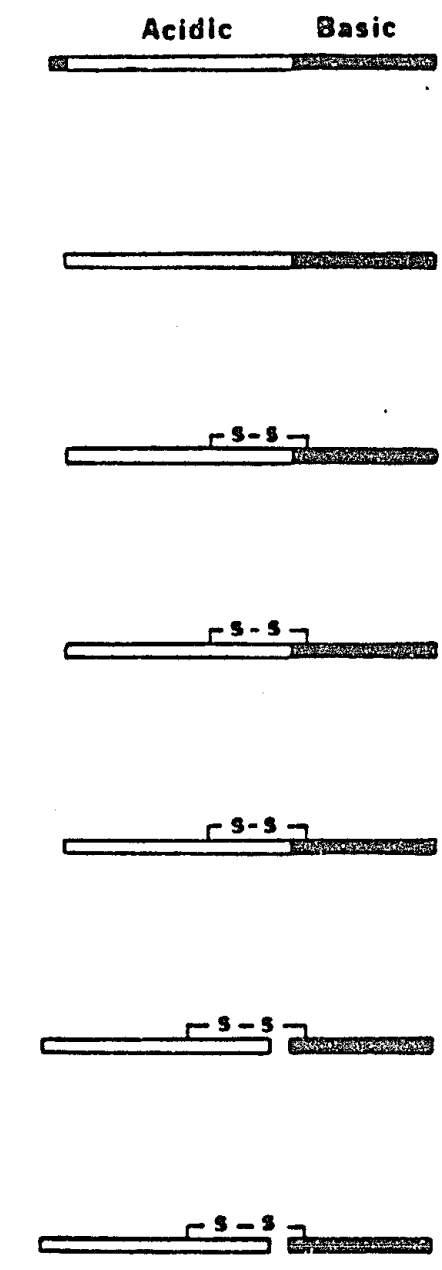

Oligemer Intracellular

Composition Compartment

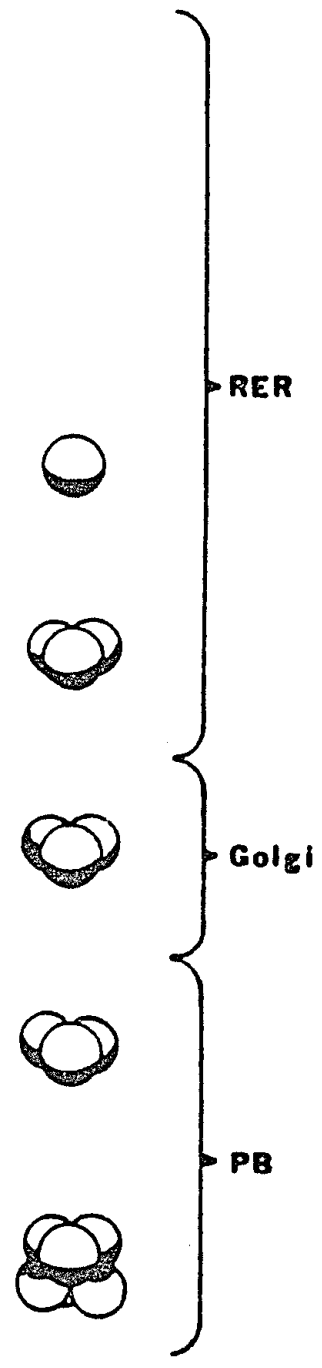

Figure 1. Mechanism for $11 \mathrm{~S}$ protein synthesis (Shotwell and Larkins, personal communication) 
after translation is complete the $11 \mathrm{~S}$ and $7 \mathrm{~S}$ precursors appear to assemble into trimers within the RER and are then transported to vacuoles via the Golgi apparatus. Transport from the Golgi to the vacuoles is thought to involve small membrane vesicles. After deposition in the vacuole, the $11 \mathrm{~S}$ precursors are cleaved into acidic and basic polypeptides, which remain linked by a disulfide bond. The $11 \mathrm{~S}$ type trimers then assemble into hexamers. Electron microscopic studies showed that the 11S hexamer is composed of two stacked subunit trimers (Reichelt et al., 1980). To a large extent, the molecular structure of the $11 \mathrm{~S}$ and $7 \mathrm{~S}$ globulins are conserved among species.

A study of oat 11S globulin (Peterson and Brinegar, 1986) reported large and small polypeptide size ranges (molecular weights) of 32,000 - 37,000 (alpha polypeptides) and 22,000 - 24,000 (beta polypeptides). These polypeptides are linked by disulfide bonds. In addition to the size difference between the oat globulin alpha and beta polypeptides, their charge properties are also dissimilar, beta polypeptides being more basic. By taking advantage of these charge differences they were separated by ion exchange chromatography.

Amino acid analysis of the whole globulin and the alpha and beta polypeptide groups of the oat 11S protein (Peterson and Brinegar, 1986) was consistent with their isoelectric focusing mobilities. The basic amino acid content (lysine, histidine, and arginine) of the beta polypeptide group was $27 \%$ higher (on a molar basis) than the alpha group and most likely had a higher ratio of amide to acidic amino acids. As would be expected, the amino acid content of the whole globulin was intermediate to those of the alpha and beta groups. Analogies were noted between the oat globulin and legume $11 \mathrm{~S}$ storage proteins regarding their 
polypeptide and native molecular weights, interchain disulfide bonding, native structure, and acidic and basic nature of the two polypeptide groups.

The purpose of this study was to isolate and purify the quinoa storage protein (chenopodin). Chenopodin was separated into A and B subunits. Amino acid analysis was done on the purified subunits. 


\section{Materials and Methods}

Electrophoresis. Sodium dodecyl sulfate-polyacrylamide gel electrophoresis (SDS-PAGE) with discontinuous buffer systems was performed according to Laemmli (1970). All chemicals for electrophoresis were obtained from Bio-Rad Chemical Company (Richmond, CA). Acrylamide stock was made with $30 \%$ acrylamide monomer and $2.7 \%$ crosslinker. The running and stacking gels were composed of $12.5 \%$ and $4 \%$ acrylamide, respectively. Protein samples in solution were diluted with equal volumes of sample buffer containing $0.125 \mathrm{M} \mathrm{Tris-HCl}(\mathrm{pH}$ 6.8), $4 \%$ SDS, $20 \%$ glycerol, $10 \%$ 2-mercaptoethanol, and $0.01 \mathrm{mg} / \mathrm{ml}$ bromophenol blue. The samples were heated for $3 \mathrm{~min}$ at 95 degree $\mathrm{C}$ and then loaded along with molecular weight standards. Samples were electrophoresed at $25 \mathrm{~mA}$ in a Hoeffer vertical slab gel apparatus (Hoeffer Scientific Instruments, San Francisco, CA). Gels were stained in a solution containing 50\% methanol, $10 \%$ acetic acid, and $0.125 \%$ Coomassie Blue R-250 overnight with shaking. Stained gels were destained in $20 \%$ methanol, $10 \%$ acetic acid with shaking. Molecular weights of quinoa seed polypeptides were estimated from a standard curve of log molecular weight vs. relative mobility.

Protein Assay. Quantitative protein analysis was performed following a modified method of Bradford (1976). Bradford reagent $(4.8 \mathrm{ml})$ was added to $200 \mathrm{ul}$ of diluted samples (diluted with distilled water). The samples were vortexed and allowed to sit for $5 \mathrm{~min}$ at room temperature. The samples were assayed relative to 0-120 ug BSA standards and read at $595 \mathrm{~nm}$ in a Spectronic 20 spectrophotometer (Baush \& Lomb Inc., Rochester, NY). 
Seed Protein Extraction Quinoa seeds (cv. Ancient Harvest) were obtained from a local health food store. Seeds $(100 \mathrm{~g})$ were ground in a Braun coffee grinder into a coarse flour. The flour was defatted with $200 \mathrm{ml}$ of cold acetone and vacuum filtered onto Whatman filter paper. The defatted flour was dried at 37 degree C.

The optimal time of extraction was determined by magnetically stirring $1 \mathrm{~g}$ lots of defatted flour with $25 \mathrm{ml}$ of $0.5 \mathrm{M} \mathrm{NaCl}, 50 \mathrm{mM}$ Tris- $\mathrm{HCl}(\mathrm{pH} 8.0)$ for $0.5,1.0,1.5$ and $2.0 \mathrm{hr}$ at room temperature. The optimal extraction volume was determined by extracting $1 \mathrm{~g}$ lots of flour for $1 \mathrm{hr}$ using various volumes of the same buffer $(10,25,50$ and $100 \mathrm{ml})$. The optimal salt concentration was determined by extracting $1 \mathrm{~g}$ lots of flour with $10 \mathrm{ml}$ of $50 \mathrm{mM}$ Tris- $\mathrm{HCl}(\mathrm{pH} \mathrm{8.0)}$ with various concentrations of $\mathrm{NaCl}(0,0.1,0.25,0.5,0.75$ and $1 \mathrm{M})$ for $1 \mathrm{hr}$. After extraction, the samples were centrifuged at $10,000 \times \mathrm{gg}$ for $10 \mathrm{~min}$ at 5 degree $\mathrm{C}$ and the supernatant assayed for protein content by the Bradford method.

Preparation of Crude Chenopodin by Acid Precipitation. A crude extract of seed protein was obtained as described above using the optimal extraction conditions, i.e., stirring at room temperature in $0.5 \mathrm{M} \mathrm{NaCl}, 50 \mathrm{mM}$ Tris- $\mathrm{HCl}(\mathrm{pH}$ 8.0) for $1 \mathrm{hr}$ at a buffer to flour ratio of $10 \mathrm{ml} / \mathrm{g}$. The extract was divided into four equal portions. A $10 \%$ acetic acid solution was slowly added dropwise with stirring to decrease the $\mathrm{pH}$ of the samples to 3.0, 4.0, 5.0 and 6.0. The samples were centrifuged as above and the pellets suspended in $0.5 \mathrm{M} \mathrm{NaCl}, 50 \mathrm{mM}$ Tris$\mathrm{HCl}(\mathrm{pH}$ 8.0). They were centrifuged as before to remove insoluble material. Bradford assays and SDS-PAGE were performed on the original extract, the supernatants after acidification, and the redissolved pellets. 
Purification of the Chenopodin by Gel Filtration Chromatography. A $1.5 \times 90$ cm Sepharose CL-6B (Pharmacia, Piscataway, NJ) column was prepared and equilibrated in $0.5 \mathrm{M} \mathrm{NaCl}, 50 \mathrm{mM}$ Tris- $\mathrm{HCl}(\mathrm{pH} \mathrm{8.0)}$ at 5 degree $\mathrm{C}$. The crude chenopodin was prepared under optimized conditions as follows: $5 \mathrm{~g}$ of flour were stirred with $50 \mathrm{ml}$ of $0.5 \mathrm{M} \mathrm{NaCl}, 50 \mathrm{mM}$ Tris- $\mathrm{HCl}(\mathrm{pH} 8.0)$ for $1 \mathrm{hr}$ at room temperature. After centrifugation at $10,000 \times \mathrm{xg}$ for $10 \mathrm{~min}$ at 5 degree $C$, the supernatant was recovered and acidified to $\mathrm{pH} 6.0$ with $10 \%$ acetic acid. The mixture was centrifuged and the pellet redissolved in $5 \mathrm{ml}$ extraction buffer at $\mathrm{pH}$ 8.0. After centrifugation to remove insoluble material, $1.5 \mathrm{ml}$ of the supernatant (about $25 \mathrm{mg}$ protein) were loaded onto the column. The column was connected to an Model UA-5 absorbance monitor (ISCO, Lincoln, NE) fitted with a $280 \mathrm{~nm}$ filter. The column was eluted at $25 \mathrm{ml} / \mathrm{hr}$ and fractions of $4 \mathrm{ml}$ were collected using an ISCO Retriever II fraction collector. Fractions containing protein, as determined by Bradford assay, were analyzed by SDS-PAGE. The native molecular weight of the chenopodin was estimated by calibrating the gel filtration column with Blue Dextran $(2,000,000 \mathrm{Da})$, thyroglobulin $(669,000 \mathrm{Da})$, ferritin $(440,000 \mathrm{Da})$, alcohol dehydrogenase $(150,000 \mathrm{Da})$, bovine serum albumin $(66,000 \mathrm{Da})$, and cytochrome c $(12,400 \mathrm{Da})$.

Protein Alkylation. The most pure chenopodin fractions from gel filtration were pooled and dialyzed against distilled water at 5 degree $\mathbf{C}$ and freeze dried (Virtis Freeze Drier, Gardiner, NY). The lyophilized protein was dissolved in $8 \mathrm{M}$ urea, 1 $\mathrm{mM} \mathrm{Na}_{2}$ EDTA (disodium ethylenediaminetetraacetic acid), $50 \mathrm{mM}$ Tris- $\mathrm{HCl}$ (pH 8.6) and $10 \mathrm{mM}$ DTE (dithioerythritol) then incubated at room temperature for 2 $\mathrm{hr}$. The denatured and reduced protein was alkylated by adding $0.1 \mathrm{ml}$ of buffer containing $8 \mathrm{M}$ urea, $1 \mathrm{mM} \mathrm{Na}_{2}$ EDTA, $50 \mathrm{mM}$ Tris-HCl $(\mathrm{pH} \mathrm{8.6)}$ and $0.2 \mathrm{M}$ 
iodoacetic acid for $30 \mathrm{~min}$ in the dark. The carboxymethylated protein was dialyzed against distilled water at 5 degree $\mathrm{C}$ and freeze dried. SDS-PAGE was performed on carboxymethylated and untreated chenopodin in the absence of 2mercaptoethanol to confirm the completeness of the alkylation reaction.

\section{Separation of Chenopodin Subunits by Ion Exchange Chromatography. A}

$0.5 \times 8 \mathrm{~cm}$ DEAE Sepharose CL-6B column was prepared and equilibrated in $6 \mathrm{M}$ urea, $20 \mathrm{mM}$ Tris- $\mathrm{HCl}(\mathrm{pH} 7.0)$ at room temperature. About $6 \mathrm{mg}$ of purified, alkylated chenopodin were dissolved in $0.3 \mathrm{ml}$ of the same buffer. The sample was loaded onto the column and step eluted with the buffer containing $0.0,0.05$, $0.1,0.15$, and $0.2 \mathrm{M} \mathrm{NaCl}$, respectively. The column was monitored at $280 \mathrm{~nm}$, eluted at $15 \mathrm{ml} / \mathrm{hr}$, and $1 \mathrm{ml}$ fractions were collected. Fractions were analyzed by SDS-PAGE. A fraction containing a pure lower molecular weight (B) subunit and a fraction containing a partially pure higher molecular weight (A) subunit were separately dialyzed against distilled water at 5 degree $C$ and freeze dried.

Amino Acid Analysis. The alkylated chenopodin, the purified B subunit, and the partially purified A subunit were acid hydrolyzed and analyzed for amino acid composition by HPLC of their phenyl isothiocyanate derivatives. Amino acid analyses were performed by the Microchemical Core Facility, Biology Department, San Diego State University. 


\section{Results and Discussion}

Seed Protein Extraction. The protein extracted from defatted quinoa seed flour at various extraction times (Table II) showed that protein yield increased up to 1 $\mathrm{hr}$ and then it started to level off to approximately $75 \mathrm{mg}$ protein $/ \mathrm{g}$ flour. A $1 \mathrm{hr}$ extraction time was chosen as optimal in order to obtain a high yield while minimizing the chances of proteolysis at longer extraction times.

Using various volumes of extraction buffer ranging from $10-100 \mathrm{ml} / \mathrm{g}$ flour had little effect on the protein yield (Table III). The optimal extraction ratio was considered as $10 \mathrm{ml} / \mathrm{g}$ in order to lessen the volume of extraction buffer and keep the protein in a more concentrated form.

Protein estimations on the extracts using buffer with various amounts of $\mathrm{NaCl}$ (Table IV) showed a steady increase in yield up to $0.75 \mathrm{M}$ (approximately $55 \mathrm{mg}$ protein $/ g$ flour). Even though $0.75 \mathrm{M}$ gave the maximum yield, $0.5 \mathrm{M} \mathrm{NaCl}$ was chosen as the optimal concentration in order to minimize the salt level while still achieving a relatively high yield.

SDS-PAGE of these samples showed little difference in polypeptide composition (Fig. 2). Four major groups of bands were resolved in each sample. The $50 \mathrm{kDa}$ protein is possibly the uncleaved (unprocessed) A (acidic) and B (basic) polypeptides of chenopodin. The A subunit group contains three resolved polypeptides of molecular weights ranging from $32-39 \mathrm{kDa}$ and the $B$ subunit group has two types of polypeptides of molecular weight 22 and $23 \mathrm{kDa}$. These $\mathrm{A}$ and $B$ polypeptide patterns are similar to those of $11 S$ storage proteins of other cereals and legumes. The lowest molecular weight protein $(8 \mathrm{kDa})$ is probably the $2 S$ storage protein. 
Table II. Effect of Extraction Time on Protein Yielda.

\begin{tabular}{cc}
\hline $\begin{array}{c}\text { Extraction } \\
\text { time } \\
\text { (hours) }\end{array}$ & $\begin{array}{c}\text { Protein yield/ } \\
\text { gram of flour } \\
(\mathrm{mg})\end{array}$ \\
\hline 0.5 & 64.4 \\
1.0 & 71.7 \\
1.5 & 74.3 \\
2.0 & 75.9 \\
& \\
am of flour $+25 \mathrm{ml}$ buffer, extracted for various times at room
\end{tabular}

aOne gram of
temperature. 
Table III. Effect of Extraction Volume on Protein Yielda.

\begin{tabular}{cc}
\hline $\begin{array}{c}\text { Extraction } \\
\text { volume } \\
(\mathrm{ml})\end{array}$ & $\begin{array}{c}\text { Protein yield/ } \\
\text { gram of flour } \\
(\mathrm{mg})\end{array}$ \\
\hline 10 & 66.3 \\
25 & 64.9 \\
50 & 66.9 \\
100 & 61.5
\end{tabular}

aOne gram of flour with varying volume of buffer, extracted for one hour. 
Table IV. Effect of $\mathrm{NaCl}$ Salt Concentration on the Protein Yielda.

\begin{tabular}{cc}
\hline $\begin{array}{c}\text { Salt } \\
\text { concentration } \\
\text { (moles/liter) }\end{array}$ & $\begin{array}{c}\text { Protein yield/ } \\
\text { gram of flour } \\
\text { (mg) }\end{array}$ \\
\hline 0.0 & 38.9 \\
0.1 & 37.9 \\
0.25 & 43.0 \\
0.5 & 50.7 \\
0.75 & 55.0 \\
1.0 & 55.9
\end{tabular}

aOne gram of flour $+10 \mathrm{ml}$ of buffer with varying concentrations of $\mathrm{NaCl}$, extracted for one hour. 


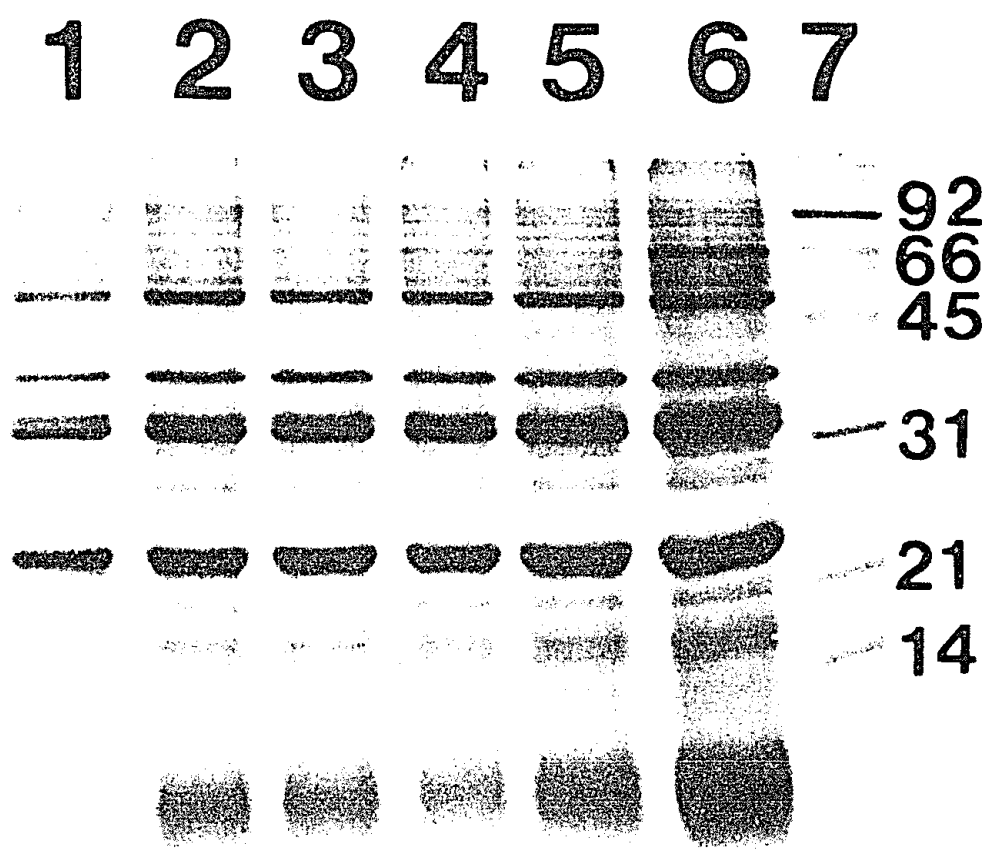

Figure 2. SDS-PAGE of quinoa seed protein extracted with different salt concentrations. Lanes $1-6$ show $0.0,0.1,0.25,0.5,0.75$ and $1.0 \mathrm{M} \mathrm{NaCl}$ extracted samples, respectively. Lane 7 contains molecular weight standards. Molecular weights of the standards are shown along the right side of lane 7 (expressed in $\mathrm{kDa}$ ). 
Preparation of Crude Chenopodin by Acid Precipitation. Protein estimation on the amount of protein precipitated at various $\mathrm{pH}$ values (Table $\mathrm{v}$ ) showed an increasing yield at lower $\mathrm{pH}$ down to $\mathrm{pH} 4.0$, but at $\mathrm{pH} 3.0$ the yield fell slightly. However, the protein yield on the redissolve, i pe!lets (at $\mathrm{pH} 8.0$ ) showed that more protein was redissolved as the $\mathrm{pH}$ of precipitation increased. For example, only $4 \%$ of the protein precipitated at $\mathrm{pH} 3.0$ could be redissolved at $\mathrm{pH} 8.0$, whereas $74 \%$ of the $\mathrm{pH} 6.0$ precipitated protein was soluble. The data indicates that at $\mathrm{pH}$ values below 5.0 , much of the precipitated protein is denatured by the acidic conditions and resists solubilization.

SDS-PAGE of these samples (Fig. 3) showed that precipitation at $\mathrm{pH} 5.0$ and pH 6.0 eliminated many minor proteins, thereby partially purifying the chenopodin. Since there was a higher yield of chenopodin by $\mathrm{pH} 5.0$ precipitation, all subsequent precipitations were performed at $\mathrm{pH}$ 5.0. At pH 3.0 there was a significant loss of $B$ subunit in the precipitated protein. This might be due to the basic nature of the $B$ subunits, because at lower $\mathrm{pH}$ values these would still have a net positive charge, whereas the A subunits would be closer to their isoelectric point. Such a selective precipitation of subunits would also indicate an acid induced disruption of the disulfide bonding between the A and B polypeptides.

Purification of Chenopodin by Gel Filtration Chromatography. Gel filtration (Fig. 4) showed there to be three distinct peaks. The first peak came in the void volume. Bradford assays showed there was no protein in the first and the third peak; therefore, the first peak is most likely high molecular weight nucleic acid, and the third peak is probably low molecular weight UV absorbing metabolites or 
Table V. Recovery of Acid Precipitated Protein.

\begin{tabular}{ccc}
\hline $\mathrm{pH}$ of precipitation & $\begin{array}{c}\% \text { of } \\
\text { total protein } \\
\text { precipitated }\end{array}$ & $\begin{array}{c}\text { \% of precipitated } \\
\text { protein } \\
\text { redissolved at } \\
\text { pH8.0 }\end{array}$ \\
\hline 3.0 & 66.8 & 4.0 \\
4.0 & 74.7 & 21.6 \\
5.0 & 67.4 & 60.0 \\
6.0 & 35.7 & 73.9
\end{tabular}




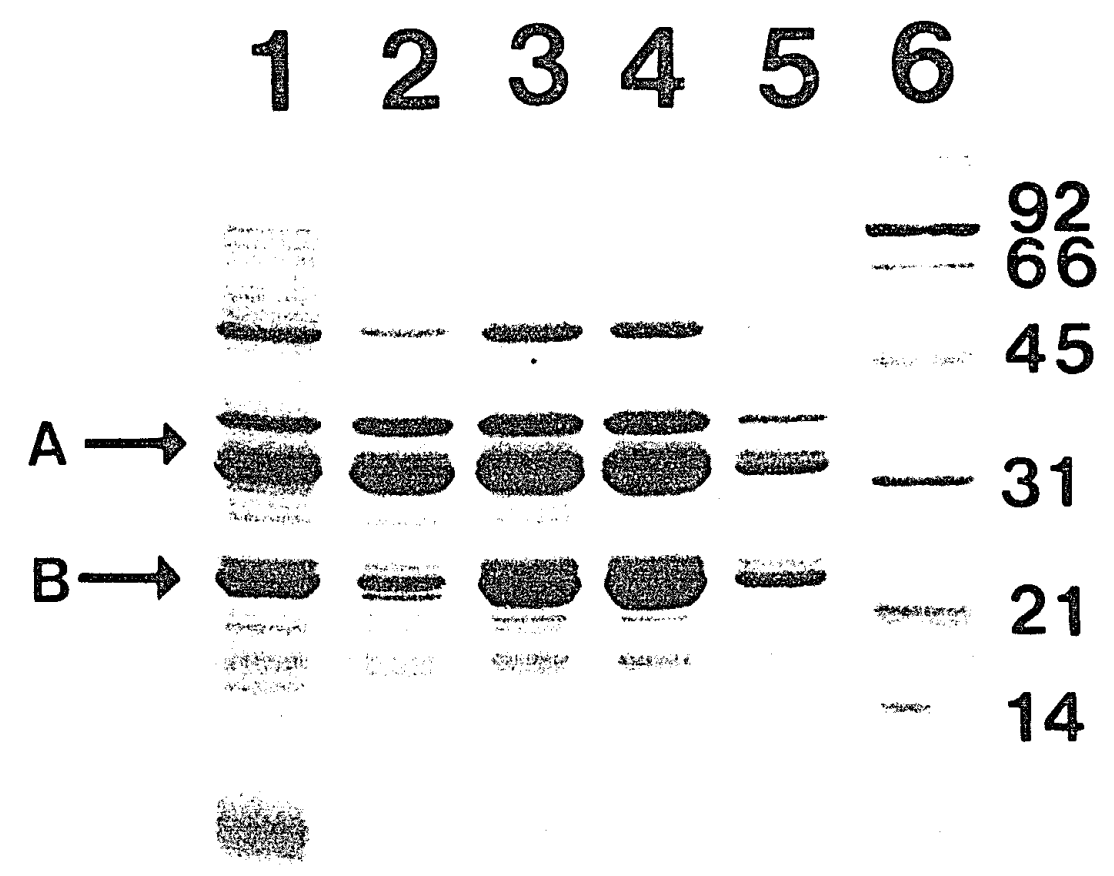

Figure 3. SDS-PAGE analysis of protein precipitated at various pH's. Lane 1 shows the original extract before acidification. Lanes 2-5 show protein precipitated after extracts were acidified to $\mathrm{pH} 3.0,4.0,5.0$ and 6.0, respectively. Lane 6 contains the molecular weight standards. The A and B subunit groups of chenopodin are marked by arrows. 
pigments. SDS-PAGE (Fig. 5) of the fractions in the second peak showed the presence of the chenopodin polypeptides. The ascending part of the peak, however, eliminated the $50 \mathrm{kDa}$ polypeptide from the chenopodin subunits. The fractions in the ascending peak were pooled, dialyzed against distilled water, and freeze dried to give a pure chenopodin preparation. The estimated native molecular weight of chenopodin was 316,000 .

Protein Alkylation. Since all other known 11S seed proteins have their two subunit groups joined by disulfide bonds, it was necessary to denature, reduce, and alkylate the protein before attempting to isolate the $A$ and $B$ subunit groups. To confirm that the alkylation was complete, the carboxymethylated protein was analyzed by SDS-PAGE without a disulfide reducing agent (2-mercaptoethanol) in the sample buffer (Fig. 5, lane 3). The A and B polypeptides were well resolved. When the non-alkylated protein was run under the same conditions (lane 2), bands appeared near $50 \mathrm{kDa}$ representing the disulfide bonded A-B species. These data indicate that alkylation proceeded to near completion.

\section{Separation of Chenopodin Subunits by Ion Exchange Chromatography.}

DEAE ion exchange chromatography of the denatured, alkylated chenopodin resolved several peaks (Fig. 6). SDS-PAGE (Fig. 7) of the fractions showed that the first two peaks contained the $B$ subunits. This shows that at $\mathrm{pH} 7.0$ the $B$ subunits carry fewer negative charges than the A subunits. Application of $0.1 \mathrm{M}$ $\mathrm{NaCl}$ eluted the lower molecular weight $(32 \mathrm{kDa})$ polypeptide of the $\mathrm{A}$ subunits along with trace amounts of $B$ subunit. The other polypeptides of the A subunit group were eluted by $0.15 \mathrm{M} \mathrm{NaCl}$. 


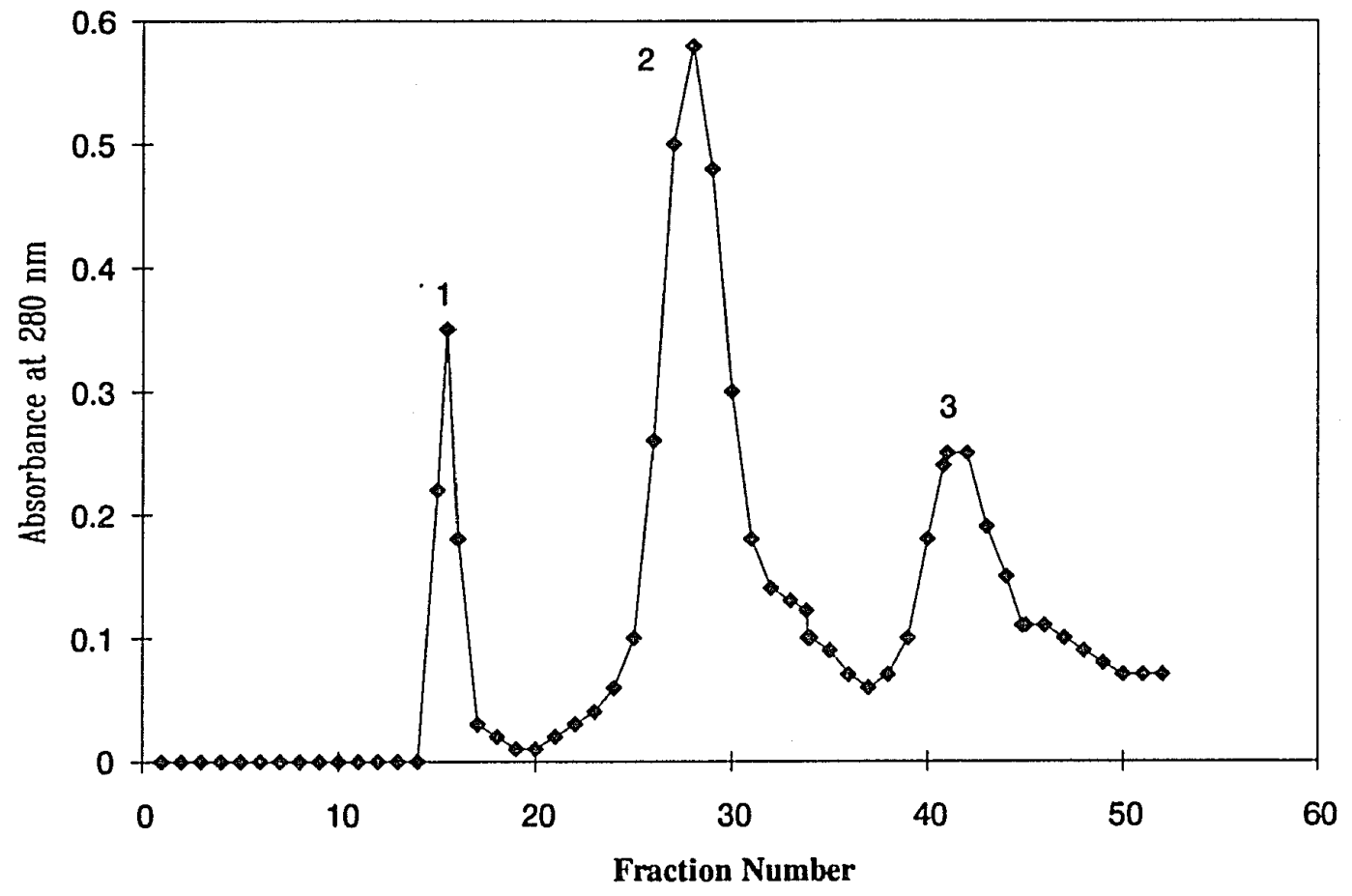

Figure 4. Sepharose CL-6B gel filtration of $\mathrm{pH} 5.0$ precipitated quinoa protein dissolved in $50 \mathrm{mM}$ Tris- $\mathrm{HCl}(\mathrm{pH} 8.0)$ and $0.5 \mathrm{M} \mathrm{NaCl}$. Column effluent was monitored at $280 \mathrm{~nm}$. 


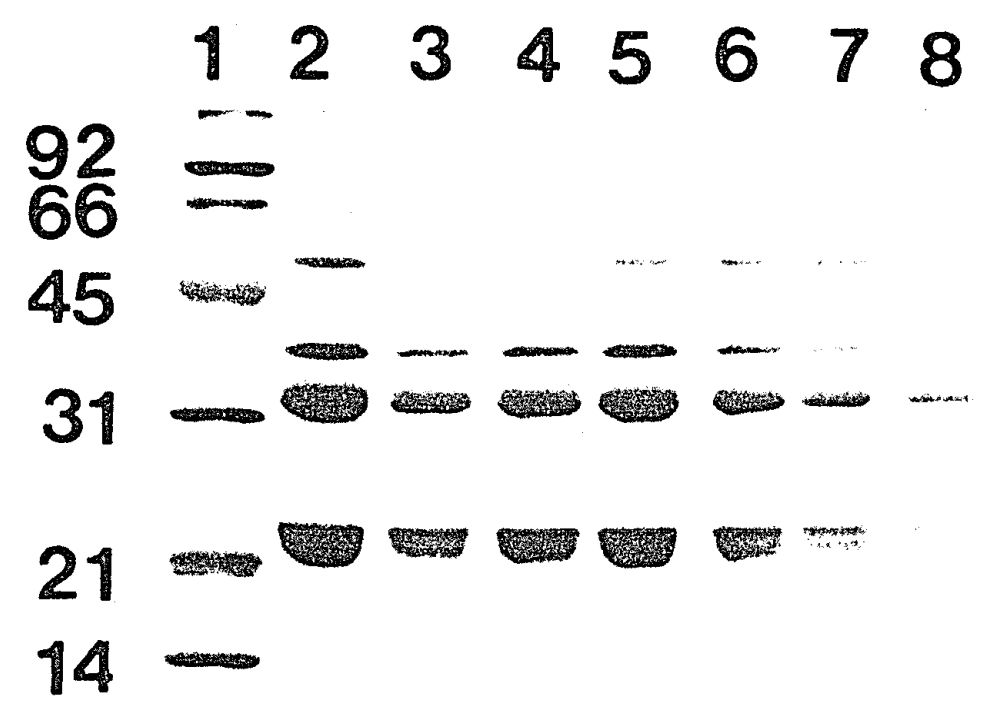

Figure 5. SDS-PAGE analysis of the gel filtration protein fractions (see Fig.4). Lane 1 contains the molecular weight standards. Lane 2 is the sample prior to chromatography, and Lanes 3-8 are column fractions 26-31, respectively. 


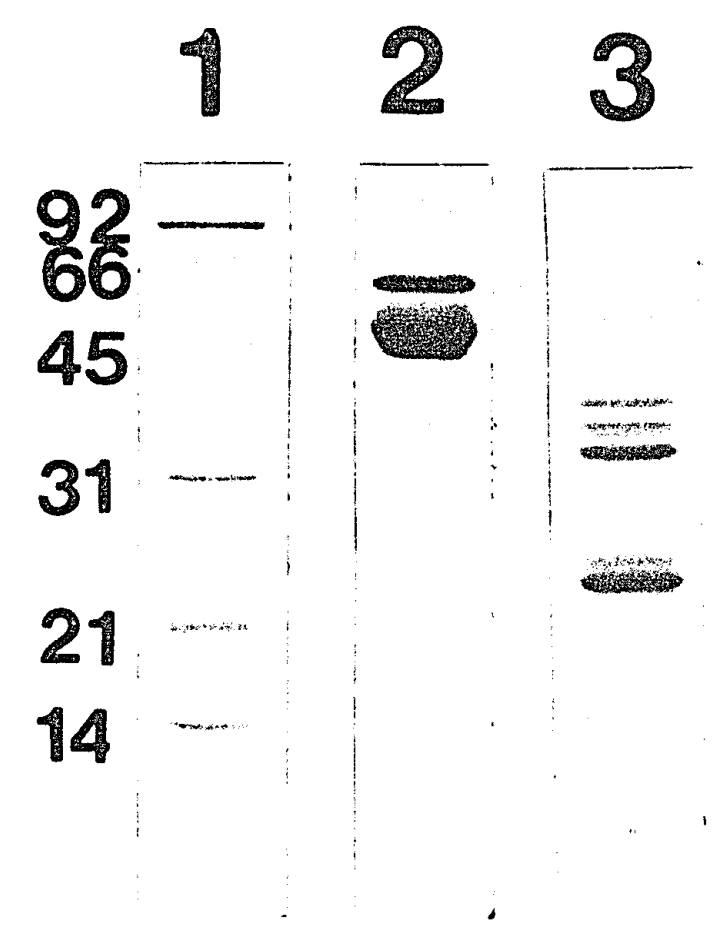

Figure 6. SDS-PAGE analysis of alkylated versus unalkylated chenopodin. Lane 1 contains the molecular weight standards. Lane 2 shows the unalkylated protein, and Lane 3 shows alkylated protein. Both samples were prepared in sample buffer without disulfide reducing agent. 


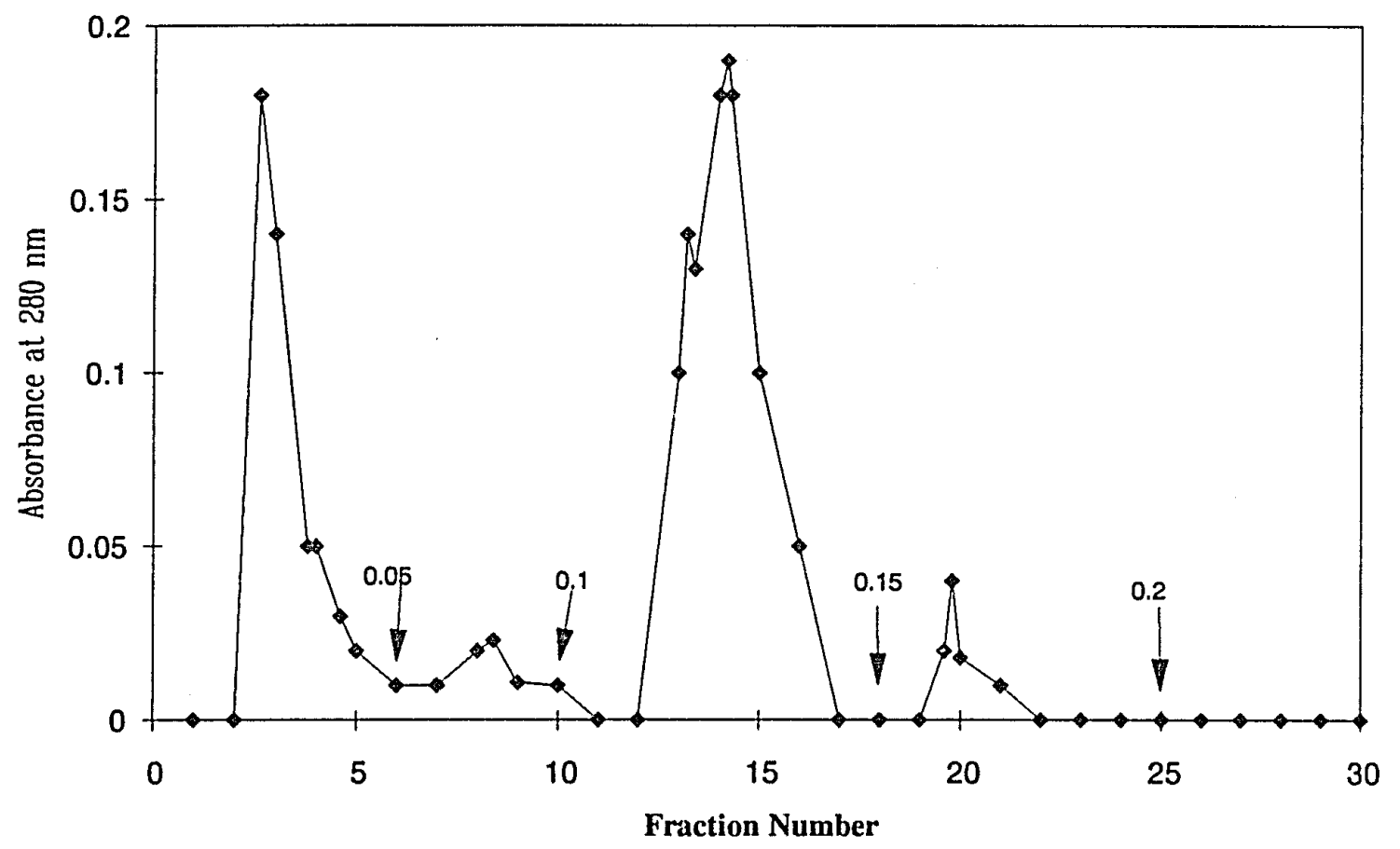

Figure 7. DEAE Sepharose CL-6B ion exchange chromatography of alkylated chenopodin dissolved in $6 \mathrm{M}$ urea, $20 \mathrm{mM}$ Tris- $\mathrm{HCl}(\mathrm{pH}$ 7.0). The column was eluted with $0.0,0.05,0.1,0.15$ and $0.2 \mathrm{M} \mathrm{NaCl}$ (arrows). 


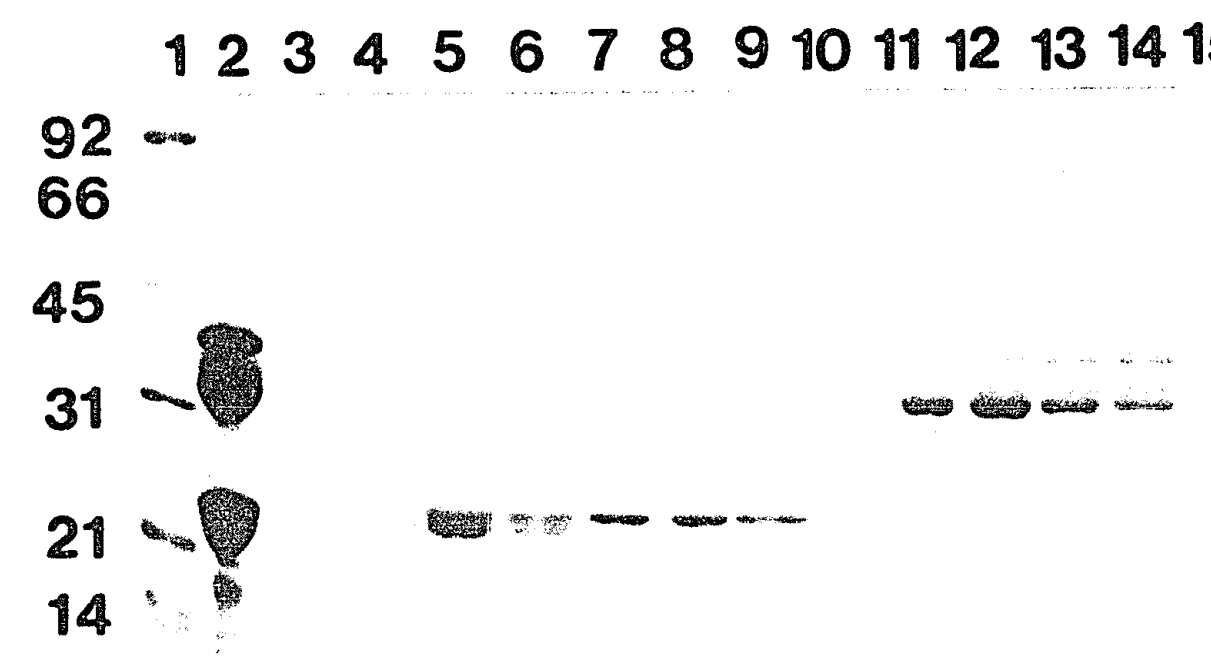

Figure 8. SDS-PAGE analysis of DEAE ion exchange chromatography fractions(see Fig.7). Lane 1 contains the molecular weight standards. Lane 2 is the sample prior to chromatography. Lanes 3-6 contain the fraction numbers 1 to 4, lanes 7-9 contain fraction numbers 7 to 9 , lanes 10-14 contain fraction numbers 12 to 16 , and lanes 15-17 contain the fraction numbers 20 to 22 . 
Amino Acid Analysis. The amino acid compositions of the whole chenopodin and its $A$ and $B$ subunits are shown in Table VI. The amino acid composition of whole chenopodin, when compared to glycinin, the soybean 11S storage protein (Kitamura and Shibasaki, 1975), is similar but somewhat higher in serine, methionine, histidine, and arginine and lower in aspartic acid/asparagine, glutamic acid/glutamine, and lysine. Comparison of the A and $B$ subunit compositions shows that the A subunit is higher in glutamic acid/glutamine, glycine, methionine, and histidine but lower in alanine, isoleucine, leucine, tyrosine, phenylalanine, and arginine. The sum of the basic amino acids lysine, arginine, and histidine are about the same in both subunits, although the $B$ subunits are considered more basic in their charge. Therefore, the amount of asparagine and glutamine must be higher in the B subunits, although these are converted to the acid forms during hydrolysis and cannot be quantitated. 
Table VI. Amino acid composition ${ }^{\mathrm{a}}$ of chenopodin and its A and B subunits.

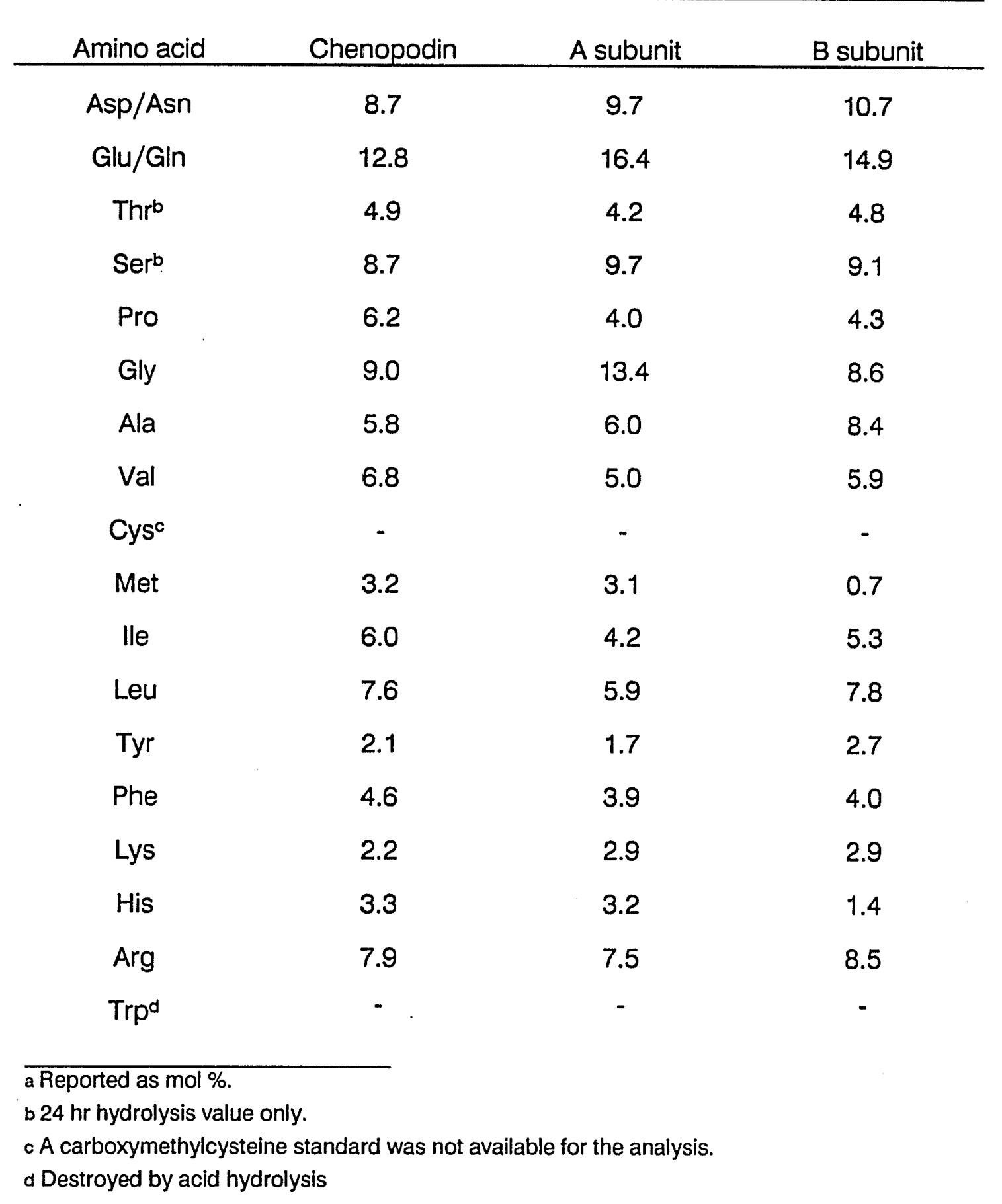




\section{Summary}

Extraction of quinoa seed protein was optimized with regard to extraction time, $\mathrm{NaCl}$ concentration, and buffer volume to flour ratio. The optimal conditions were extraction in $0.5 \mathrm{M} \mathrm{NaCl}, 50 \mathrm{mM}$ Tris-HCL, $\mathrm{pH} 8.0$ for $1 \mathrm{hr}$ at room temperature using $10 \mathrm{ml}$ buffer per $\mathrm{g}$ flour. The extract was shown to contain four major polypeptide groups as determined by SDS-PAGE: the chenopodin A and $B$ subunit groups (at $32-39 \mathrm{kDa}$ and $22-23 \mathrm{kDa}$, respectively), a $50 \mathrm{kDa}$ polypeptide, and a group of unresolved polypeptides at 8-9 kDa. Acidification of the extract to pH 5.0 caused the precipitation and significant enrichment of chenopodin.

Gel filtration chromatography of this crude preparation yielded pure chenopodin. After reduction and alkylation, pure chenopodin was separated into its $A$ and $B$ subunits by ion exchange chromatography. Amino acid analysis of whole chenopodin showed similarities to other $11 S$ proteins. The A subunit group was higher in glycine, methionine, and histidine than the B subunits, but lower in alanine, leucine, and phenylalanine.

An important reason to study the structure of quinoa storage proteins is the possibility of future genetic engineering. Techniques are now available whereby genes can be transferred from one plant species to another and expressed in the new host. The ability to transform plants with storage protein genes provides a tool to address important questions pertaining to gene regulation as well as the synthesis and processing of these proteins. Research is in progress to use CDNA clones to find the nuclear genes encoding storage proteins (Bright and Shewry, 1983). 
The potential for genetically manipulating plants is immense and many companies have been established with the aim of exploiting these possibilities. In the future, one of these companies may produce a nutritionally improved variety of wheat or corn containing quinoa proteins. 


\section{LITERATURE CITED}

Becker, R.; Hanners, G.D. Compositional and nutritional evaluation of quinoa whole grain flour and mill fractions. Lebensm.-Wiss. Technol. 1990, 23, 441444.

Bradford, M.M. A rapid and sensitive method for quantitation of microgram quantities of protein utilizing the principle of protein-dye binding. Anal. Biochem. 1976, 72, 248-254.

Fairbanks, D.J.; Burgener, K.W.; Robison, L.R.; Andersen, W.R.; Ballon, N.E. Electrophoretic characterization of quinoa seed proteins. Plant Breeding, $1990,104,190-195$.

Gonzalez, J.A.; Roldan, A.; Gallardo, M.; Escudero, T.; Prado, F.E. Quantitative determinations of chemical compounds with nutritional value from Inca crops Chenopodium quinoa. Plant Foods Hum. Nutr., 1989, 39, 331-338.

Gross, R.; Koch, F.; Malaga, I.; De Miranda, A.F.; Schoenberger, H.; Trugo, L.C. Chemical composition and protein quality of some local Andean food sources. Food Chemistry, 1989, 34, 25-34.

Johnson, D.C.; Croissant, R.L. Quinoa production in Colorado. Service in Action - Colorado State University Cooperative Extension, 1985, no.112.

Kitamura, K.; Shibasaki, K. Isolation and some physico-chemical properties of the acidic subunits of soybean 11 globulin. Agric. Biol. Chem., 1975, 39, 945-951. 
Laemmli, U.K. Cleavage of structural proteins during the assembly of the head of bacteriophage T4. Nature. 1970, 227, 680-685.

Peterson, D.M.; Brinegar, A.C. Oat storage proteins. In Oats: Chemistry and Technology; Webster, F.H., Ed.; American Association of Cereal Chemists, Inc.: Minneapolis, 1986; Chapter 7, pp. 153-165.

Sokolov, R. This is quinoa. Natural History, 1992, 6, 72-75.

Wood, T.R. Tale of a food survivor. East West Journal, 1985, 4, 63-68, 